\title{
ANTAGONISTIC EFFECT OF YEAST, ACETIC ACID BACTERIA AND MANGOSTEEN RIND EXTRACT ON AFLATOXIGENIC Aspergillus flavus IN UNFERMENTED COCOA BEANS
}

\author{
NIJMA NURFADILA ${ }^{1,2}$, SUTRISNO $^{2}$, USMAN AHMAD $^{2}$ AND SAMSUDIN $^{3}$ \\ 'SEAMEO BIOTROP, Jalan Raya Tajur Km. 6, Bogor 16134, Indonesia \\ ${ }^{2}$ Study Program of Postharvest Technology, Faculty of Agricultural Technology, Institut Pertanian Bogor, Bogor 16680, Indonesia \\ ${ }^{3}$ Balai Penelitian Tanaman Industri dan Penyegar (BALITTRI), Parungkuda, Sukabumi, Indonesia 43357
}

Received 22 May 2020 / Accepted 6 January 2021

\begin{abstract}
Yeasts and bacteria are two of common biocontrol agents to control mycotoxigenic fungi. Meanwhile, the mangosteen rind extract contains xanthone and gartanin compounds for antioxidant, antiproliferation, antiinflammation, antimicrobial, and anticancer. The objectives of this research were to test the effects of yeasts, acetic acid bacteria (AAB), and mangosteen rind extract on the aflatoxigenic Aspergillus flavus growth and aflatoxin production in unfermented cocoa beans. Four yeast isolates, i.e., Issatchenkia orientalis (Io) BIO 211291, 286 and 288, and Endomyces fibuliger (Ef) BIO 132219; one bacteria isolate of Acetobacter aceti (Aa) FNCC0016; and mangosteen rind extract (MRE) were tested for their capabilities in inhibiting an aflatoxigenic $A$. flavus (Af) $\mathrm{BIO}$ $3361 / 747$ growth using the well method (in vitro). Two types of yeast (Io BIO 211291 and 288) were combined with $A a$ and MRE in cocoa beans (in vivo). Aflatoxin production was analyzed using Thin Layer Chromathograpby (TLC). The results showed that interaction of Io BIO 211291 and 288, and Ef BIO 132219 on aflatoxigenic Af were interaction with inhibition zone $\geq 2 \mathrm{~mm}$ (type D), while the interaction type of Io BIO 211286 on $A f$ were mutual intermingling growth, where both fungi grew into each other without any macroscopic sign of interaction (type A). The best treatment in agar media (in vitro) was Io BIO $211288+$ Aa on Potato Dextrose Agar + $12 \mathrm{~g} / \mathrm{L}$ MRE. The highest Io population was $5.88 \mathrm{log} \mathrm{cfu} / \mathrm{g}$ on cocoa beans inoculated by Io BIO $211291+\mathrm{MRE}$ in 1 day after inoculation, while the highest $A$. aceti population was $4.74 \mathrm{log} \mathrm{cfu} / \mathrm{g}$ on cocoa beans with Io BIO 211291 + BIO $211288+A a$ in 3 days after inoculation. Two best treatments were Io BIO $211288+A a+$ MRE and Io BIO $211291+$ BIO $211288+A a+$ MRE, because there were no A. flavus population since 3 until 11 days after inoculation. Aflatoxin in all samples treatment was lower than limit detection $\mathrm{B}_{1}(<2.20 \mathrm{ppb}), \mathrm{B}_{2}(<3.50 \mathrm{ppb})$, $\left(\mathrm{G}_{1}<0.54 \mathrm{ppb}\right)$, dan $\left(\mathrm{G}_{2}<1.00 \mathrm{ppb}\right)$.
\end{abstract}

Keywords: aflatoxin, antagonistic, Aspergillus flavus, mangosteen rind, yeasts

\section{INTRODUCTION}

Indonesia is the $3^{\text {rd }}$ cocoa beans exporter countries after Ivory Coast and Ghana (Dickson 2018). Agricultural Department (2010) reported as much as $93 \%$ of cocoa beans in Indonesia was processed without fermentation (only sundried) conducted by farmers, while the remaining $7 \%$ of cocoa beans was processed by fermentation. Thompson et al. (2013) explained that cocoa beans fermentation process involves

\footnotetext{
"Corresponding author, email: n.nurfadila@yahoo.co.id;
} nijma@biotrop.org some microorganisms, i.e., yeasts, acetic acid bacteria $(\mathrm{AAB})$, lactic acid bacteria (LAB), Bacillus and several other bacteria, as well as filamentous fungi. According to Nurhansyah (2011) some importer countries such as Malaysia and United States of America reduced the amount of cocoa beans import from Indonesia, because the physicochemical quality of Indonesian cocoa beans were lower than those from Africa. The decreasing of cocoa beans quality was caused by unappropriate handling during the harvesting, fermentation, drying, storing, and packaging processes that facilitates fungal contamination. 
According to Asrul (2009) unfermented cocoa beans and mycotoxigenic fungi contamination, especially aflatoxigenic Aspergillus flavus, were problems in Indonesia. Some fungi were isolated from cocoa beans in Central Sulawesi, i.e., Aspergillus flavus, A. niger, A. fumigatus, Penicillium sp., Fusarium sp., Trichoderma sp., T. viride, Rhizopus sp., Mucor sp., Verticillium sp., and Geotrichum sp. Aspergillus flavus was isolated in cocoa beans after being harvested by farmers $\left(7.2 \times 10^{8} \mathrm{cfu} / \mathrm{mL}\right)$, collector $\left(4.5 \times 10^{5} \mathrm{cfu} / \mathrm{mL}\right)$, and exporter levels $\left(4.1 \times 10^{3} \mathrm{cfu} / \mathrm{mL}\right)$. Aflatoxin $\mathrm{B}_{1}$ content in cocoa beans after being harvested by farmers (104.80 ppb), collectors (61.31 ppb), and exporters (47.74 ppb). Copetti et al. (2011) reported the occurrence of aflatoxigenic fungi and the presence of aflatoxin in 226 cocoa samples collected in Brazilian farms. The aflatoxigenic fungi isolated in cocoa beans were A. flavus, $A$. parasiticus and $A$. nomius. A considerable increase in numbers of these species was observed during drying and storage processes. Pires et al. (2019) explained that the total aflatoxins in two cocoa bean samples from their study, from Bahia, from Pará and from Rondônia were $13.2,16.3,11.7$, and $30 \mu \mathrm{g} / \mathrm{kg}$, respectively.

According to Basappa (2009) aflatoxin is a kind of toxins produced by $A$. flavus and A. parasiticus that causes liver cancer in human and animals. The types of aflatoxins found in foodstuffs and processed products are $B_{1}, B_{2}, G_{1}$, and $G_{2}$, but the most dangerous for human health is aflatoxin $\mathrm{B}_{1}$ (AFB1).

One of the problems in unfermented cocoa beans is aflatoxigenic fungi contamination. Therefore, formulating and concocting a combination treatment to inhibit aflatoxigenic fungi is necessary. Combinations of yeast, acetic acid bacteria, and mangosteen rind extract were used for testing the effectiveness in decreasing aflatoxigenic $A$. flavus population and aflatoxin production. Dharmaputra et al. (2018a) reported that Issactchenkia orientalis could inhibit $100 \%$ of ochratoxigenic $A$. ochraceus. It means that $I$. orientalis can be used as biocontrol agent, eventhough there is no one research explains that $I$. orientalis can inhibit aflatoxigenic $A$. flavus. Sabahannur and Ralle (2018) reported not only yeast, but Acetobacter aceti also supposed to maintain shelf life of food stuff. Meanwhile
Yatman (2012) explained that mangosteen can be used as medicine, because it contains xanthone for antioxidant, antiproliferation, antiimflammatory, antitumor, and anticancer. Research conducted by Akao et al. (2008) showed that xanthone $\alpha$-mangostin compound of mangosteen rind exract could inhibit $50 \%$ of colon cancer cells growth. The inhibitive nature of the compound is similar with commercially available anticancer drugs, i.e., 5-FU, actinomycin D, and campotechin. Aisha et al. (2012) reported that xanthone extract, $\alpha$ mangostin, and $\gamma$-mangostin inhibited $50 \%$ of cancer cell in $6.5 \pm 1.0 \mathrm{mg} / \mathrm{mL}, 5.1 \pm 0.2$ $\mu \mathrm{g} / \mathrm{mL}$, and $7.2 \pm 0.4 \mu \mathrm{g} / \mathrm{mL}$. Therefore, combinations between yeast, acetic acid bacteria $(\mathrm{AAB})$ and mangosteen rind extract (MRE) is expected to produce biocontrol agent on aflatoxigenic $A$. flavus growth and decrease aflatoxin production in unfermented cocoa beans to be safe for next processing of chocolate products.

The objectives of this research were to test the effects of yeasts, acetic acid bacteria (AAB), and mangosteen rind extract on the aflatoxigenic A. flavus growth and aflatoxin production in unfermented cocoa beans. It is expected that the research result would show a potential combination of yeast, acetic acid bacteria (AAB), and mangosteen rind extract (MRE) as biocontrol agent to inhibit aflatoxigenic $A$. flavus to improve food safety in unfermented cocoa beans.

\section{MATERIALS AND METHODS}

\section{Yeast Isolates, Acetic Acid Bacteria, Aflatoxigenic Fungus, Unfermented Cocoa Beans, and Mangosteen Rind Extract}

As many as four yeast isolates were used in interaction types and antagonistic test, i.e., 1 isolate of Endomyces fibuliger (Ef) BIO 132219 and three isolates of Issatchenkia orientalis (Io) BIO 211286, BIO 211288, and BIO 211291; only two yeast isolate were used in cocoa beans (in vivo) that showed the highest percentage of inhibition on A. flavus in vitro, i.e., I. orientalis BIO 211291 and BIO 211288. Aflatoxigenic Aspergillus flavus BIO 3361/747 were obtained from Phytopathology Laboratory Culture Collections, 
SEAMEO BIOTROP; and 1 acetic acid bacteria isolate (Acetobacter aceti FNCC0016) was obtained from Food and Nutrition Study Centre, Universitas Gadjah Mada, Yogyakarta. As much as $62 \mathrm{~kg}$ of unfermented cocoa beans were obtained from Sumedang Regency, West Java Province. As much as $2 \mathrm{~kg}$ of mangosteen rind extracts was obtained from RJ Herbal, Surabaya, East Java Province.

\section{Interaction Types Test Between Yeast and Aflatoxigenic $A$. flavus}

Four yeast isolates were tested on aflatoxigenic $A$. flavus $\mathrm{BIO} 3361 / 747$ using direct opposition method (Dharmaputra et al. 2018b) (Fig. 1). This method was used to determine the interaction types between the yeasts and aflatoxigenic $A$. flavus. Aflatoxigenic Aspergillus flavus BIO 3361/747 was inoculated after 4 days of each yeast inoculation in the middle of Potato Dextrose Agar (PDA) media in petri dishes (a diameter of $9 \mathrm{~cm}$ ) with a distance of $3 \mathrm{~cm}$ between each other. The petri dishes with each fungal and yeast were then incubated at room temperature $\left(27 \pm 2^{\circ} \mathrm{C}\right)$ for 7 days. Five replicates were used for each isolates. The observation on the interaction types was conducted macroscopically between the yeast and aflatoxigenic $A$. flavus (Wheeler and Hocking 1993). The interaction types were shown in Table 1.

The mathematical equation for calculating the percentage of inhibition between the yeast and aflatoxigenic $A$. flavus is as follows:

$$
H=\frac{J_{1}-J_{2}}{J_{1}} \times 100
$$

Notes: $\% \mathrm{I}=$ percentage of inhibition, $\mathrm{J}_{1}=$ diameter of A. flavus near to petridish, $\mathrm{J}_{2}=$ diameter of $A$. flavus near to yeast.

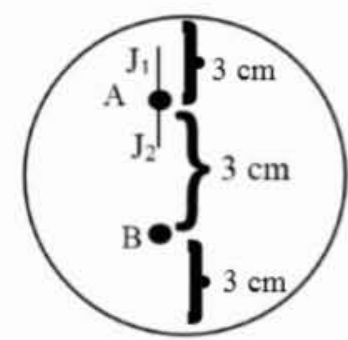

Figure 1 Scheme of antagonisms test between yeast isolate and toxigenic $A$. flavus; $\mathrm{A}=$ toxigenic $A$. flavus, $\mathrm{B}=$ yeast isolate, $\mathrm{J}_{1}=$ diameter of $A$. flavus near to petridish, $\mathrm{J}_{2}=\operatorname{diameter}$ of $A$. flavus near to yeast

Table 1 Interaction types between two fungal colonies (Wheeler \& Hocking 1993)

\begin{tabular}{cl}
\hline Type of interaction & \multicolumn{1}{c}{ Description of classification } \\
$\mathrm{A}$ & $\begin{array}{l}\text { Mutual intermingling growth, where both fungi grew } \\
\text { into each other without any macroscopic signs of } \\
\text { interaction }\end{array}$ \\
$\begin{array}{l}\text { Mutual inhibition on contact or space between } \\
\text { colonies small }(<2 \mathrm{~mm})\end{array}$ \\
$\mathrm{I}$ \\
$\begin{array}{l}\text { Inhibition of one species on contact, the inhibited } \\
\text { rate, while the inhibitor species grew at a slightly } \\
\text { reduced rate or unchanged } \\
\text { Mutual inhibition at a distance }>2 \text { mm) }\end{array}$ \\
$\mathrm{E} \quad \begin{array}{l}\text { Inhibition of one species on contact, the inhibitor } \\
\text { species continuing to grow at a reduced rate through } \\
\text { the inhibited colony }\end{array}$ \\
$\begin{array}{l}\text { Inhibition of one species on contact or at a distance, } \\
\text { the inhibitor species then continuing to grow at an } \\
\text { unchanged rate through or over the inhibited colony }\end{array}$
\end{tabular}

Notes: a: inhibitor fungi, b: inhibited species. 


\section{Obtaining of Unfermented Cocoa Beans and Mangosteen Rind Extract}

Ripe lindak cocoa (bulk cocoa) fruits with yellow color were harvested using sterile scissors from the trees. The cocoa beans were were then cut open using a knife and separated into parts of pods and cocoa beans with pulp. The next process were washing of cocoa beans from pulp and drying using sun-drying for 1 day ( 9 hours) to become unfermented cocoa beans. Obtaining of mangosteen rind extract is shown in Figure 2.

As much as $12 \mathrm{~g} / \mathrm{L}$ of mangosteen rind extract (MRE) was used in in vitro stage, while $12 \mathrm{~g}$ for $500 \mathrm{~g}$ of cocoa beans used in in vivo stage. According to Kusumaputri (2011), Dr. Berna Eliya as a phytochemist in Universitas Indonesia, explained that many people consume a glass of boiled water containing mangosteen rind extract. They usually use $60 \mathrm{~g}$ of fresh mangosteen rind equal to $12 \mathrm{~g}$ of mangosteen rind extract for 1 day. The doses of mangosteen rind extract (MRE) was obtained based on consumer's doses in MRE capsule product, as follows:

$$
\begin{aligned}
& D E=\frac{J K \times B E}{B K} \\
& D E=\frac{60 \text { capsules } \times 400 \mathrm{mg}}{2 \text { capsules }} \\
& D E=12,000 \mathrm{mg}=12 \mathrm{~g}
\end{aligned}
$$

Notes: $\mathrm{DE}=$ doses of mangosteen rind extract $(\mathrm{g}), \mathrm{JK}=$ number of capsules in 1 package of mangosteen rind extract product, $\mathrm{BE}=$ weight of mangosteen rind extract in 1 capsule $(\mathrm{mg})$, and $\mathrm{BK}=$ number of capsules to be consumed in 1 day.

\section{Antagonistic Test of Yeast, Acetobacter aceti, and Mangosteen Rind Extract Combinations on Aflatoxigenic $A$. flavus in Vitro}

Antagonistic test between yeast, Acetobacter aceti and mangosteen rind extract on aflatoxigenic $A$. flavus $\mathrm{BIO} 3361 / 747$ was conducted using the well test method (Dharmaputra et al. 2016 with modification). Acetobacter aceti FNCC0016, Issatchenkia orientalis BIO 211291, BIO 211288, BIO 211286, and Endomyces fibuliger BIO 132219) were cultured on Malt Extract Agar (MEA) media and incubated for 7 days, while the Acetobacter aceti FNCC0016 was cultured on Peptone Glucose Yeast Extract Agar (PGYA) media and incubated for 3 days at room temperature $\left(27 \pm 2{ }^{\circ} \mathrm{C}\right)$. Aflatoxigenic Aspergillus flavus $\mathrm{BIO} 3361 / 747$ was cultured on Potato Dextrose Agar (PDA) media and incubated for 7 days at room temperature $(27 \pm$ $2{ }^{\circ} \mathrm{C}$ ). Five pieces (in $5 \mathrm{~mm}$ diameter) of pure culture of each yeast were placed into $25 \mathrm{~mL}$ of Nutrient Yeast Dextrose Broth (NYDB) media in an erlenmeyer flask (100 mL volume), while the Acetobacter aceti isolate was placed into $25 \mathrm{~mL}$ of Nutrient Broth (NB) media. They were then incubated at $27 \pm 2{ }^{\circ} \mathrm{C}$ for 7 days, and were shaken for 1 hour every 24 hours for 5 days. The conidia cells of aflatoxigenic A. flavus $(5 \mathrm{x}$ $10^{6}$ cells $/ \mathrm{mL}$ ) were obtained by adding $15 \mathrm{~mL}$ of distilled water, then the A. flavus was scratched on the upper surface using sterile inoculation needle. The conidia cells were filtered by sterile gauze on the funnel of erlenmeyer flask $(100 \mathrm{~mL}$ volume).

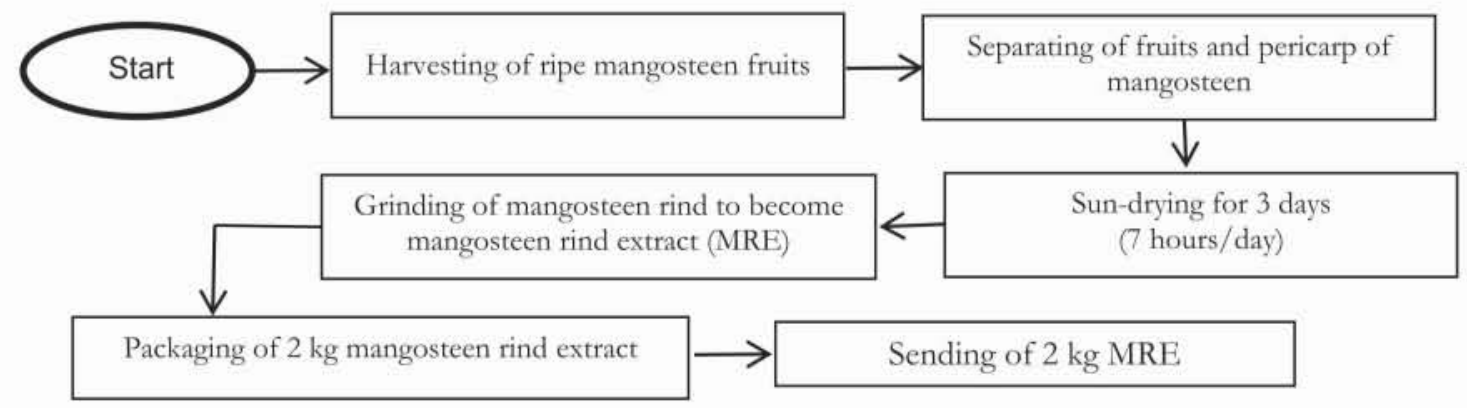

Figure 2 Stages of obtaining of mangosteen rind extract (MRE) 
The yeast, Acetobacter aceti, and A. flavus cells were precipitated by centrifugation using a centrifuge at $7,000 \mathrm{rpm}$ fixed angle rotor for 15 minutes and rinsed using twice sterile distilled water, and they were then resuspended in sterile distilledwater until the concentration reached $5 \mathrm{x}$ $10^{8}$ cells $/ \mathrm{mL}$ (yeast cells) and $5 \times 10^{6}$ cells $/ \mathrm{mL}$ (Acetobacter aceti and aflatoxigenic A. flavus). Yeasts, Acetobacter aceti and Aspergillus flavus cells were counted using a hemocytometer.

A well ( $5 \mathrm{~mm}$ diameter) was prepared using a cork borer in the center of Potato Dextrose Agar (PDA) media containing 15\% cocoa beans juice and PDA media containing 15\% cocoa beans juice and $12 \mathrm{~g} / \mathrm{L}$ of mangosteen rind extract depending on the treatments into a petri dish ( $9 \mathrm{~cm}$ diameter). As much as $20 \mu \mathrm{L}$ of $5 \times 10^{8}$ cells $/ \mathrm{mL}$ yeast cells suspension were placed into the well. The petri dishes were left for 30 minutes to allow penetration of cells suspension into the well. Next, as much as $20 \mu \mathrm{L}$ of $5 \times 10^{6}$ cells $/ \mathrm{ml}$ Acetobacter aceti was inoculated, then $A$. flavus was also inoculated into the well after 1 hour. Each yeast control was only inoculated with yeast cells suspension. Each treatment and controls were made in 3 replicates ( $=5$ petri dishes), which were then incubated at room temperature $\left(27 \pm 2{ }^{\circ} \mathrm{C}\right)$. The growth of the aflatoxigenic $A$. flavus, yeasts, and Acetobacter aceti in each petri dish was observed after 7 days of incubation. Total unit experiment for in vitro process was (4 yeast isolates x 2 within or without Acetobacter aceti $\times 2$ kinds of media $\times 3$ replicates $)+((4$ yeast control $+1 A$. flavus control) $\times 3$ replicates $)=63$. The radius of aflatoxigenic $A$. flavus colony in each petri dish was measured before the colony reached to petri dish. Mathematical equation for the percentage of fermentor inhibition to aflatoxigenic $A$. flavus is:

$\% I=\frac{D_{t}-D_{2}}{D_{1}} \times 100$

Notes: $\% \mathrm{I}=$ percentage of inhibition, $\mathrm{D}_{1}=$ diameter of A. flavus control (mm), $\mathrm{D}_{2}=$ diameter of $A$. flavus in each treatment $(\mathrm{mm})$.

Testing of Combination Treatments to Inhibit Aflatoxigenic Aspergillus flavus in Vivo

As many as two yeast isolates with the highest percentage of inhibition in vitro stage, Acetobacter aceti FNCC0016, and Aspergillus flavus
BIO 3361/747 were used in vivo stage. The steps in the testing of the combination treatments to inhibit aflatoxigenic $A$. flavus in vivo were similar to in vitro. Each treatments included positive and negative controls using $500 \mathrm{~g}$ of unfermented cocoa beans for each replicates. As much as $10 \mathrm{~mL}$ of $10^{8}$ cells $/ \mathrm{mL}$ yeast cells suspension were placed into $500 \mathrm{~g}$ of unfermented cocoa beans depending on the treatments. Each samples was then inoculated or not inoculated by $10 \mathrm{~mL}$ of $10^{6}$ cells $/ \mathrm{mL}$ A. aceti (depend on the treatments) after $30 \mathrm{~min}$, then as much as $10 \mathrm{~mL}$ of $10^{6}$ cells $/ \mathrm{mL}$ aflatoxigenic A. flavus was inoculated into the samples depending on the treatments after 1 hour. Each cells inoculation was conducted sequentially to allow the cells penetration. Total unit experiment for in vivo process was $12 \times 4 \times 2=96(12=$ types of combination including positive and negative controls; $4=$ days after inoculation $(1,3,6$ and 11); 2 = replication).

\section{Determination of Issatchenkia orientalis, Acetobacter aceti, and Aflatoxigenic Aspergillus flavus Populations, and Aflatoxin Production}

Yeast, Acetobacter aceti, and A. flavus were isolated using serial dilution method $\left(10^{-1}\right.$ up to $10^{-5}$ ), followed by pour plate method on Potato Dextrose Agar (PDA) and incubated for 7 days incubation at $27 \pm 2 \backsim$ (INS 2008). Aflatoxin contents were determined using Thin Layer Chromatoghraphy (TLC) (Baiton et al. 2006).

\section{RESULTS AND DISCUSSION}

\section{Interaction Types Between Yeast and Aflatoxigenic $A$. flavus}

As many as four yeasts (one isolate of Endomyces fibuliger BIO 132219 and three isolates of Issatchenkia orientalis BIO 211286, BIO 211288, and BIO 211291) were used in testing the mechanisms of antagonism on aflatoxigenic A. flavus $\mathrm{BIO} 3361 / 747$ using direct opposition method. The interaction type of antagonism mechanism between yeast and $I$. orientalis $\mathrm{BIO}$ $211291(49.58 \%)$ and BIO 211288 (35.79\%), and E. fibuliger $132219 \quad(49.29 \%)$ with aflatoxigenic $A$. flavus was D (Fig. 3a, 3c, 3d; Table 1). This interaction type showed that there 
was a mutual inhibition with the inhibition zone of $\geq 2 \mathrm{~mm}$ similar with Wheeler and Hocking (1993). The interaction type of I. orientalis BIO 211286 with $A$. flavus BIO $3361 / 747$ was A (Fig. $3 \mathrm{~b})$ where the percentage of each inhibition was $15.63 \%$, respectively (Table 1 ). This interaction showed mutual intermingling growth, where both fungi grew into each other without any macroscopic signs of interaction (Fig. 3; Table 1).

Based on the percentage of the inhibition of A. flavus growth using direct opposition method, three isolates (I. orientalis BIO 211291, E. fibuliger 13219, and I. orientalis BIO 211288) were higher than I. orientalis BIO 211286. It means that I. orientalis BIO 211291 and BIO 211288, and E. fibuliger BIO 13219 were prefer as potential component inhibitor for aflatoxigenic $A$. flavus in cocoa beans. Nevertheless, the three yeast isolates should be combined with additional materials to increase the ability of inhibition on aflatoxigenic $A$. flavus in unfermented cocoa beans. However, this result was strengthened in the next step using the well in vitro method.

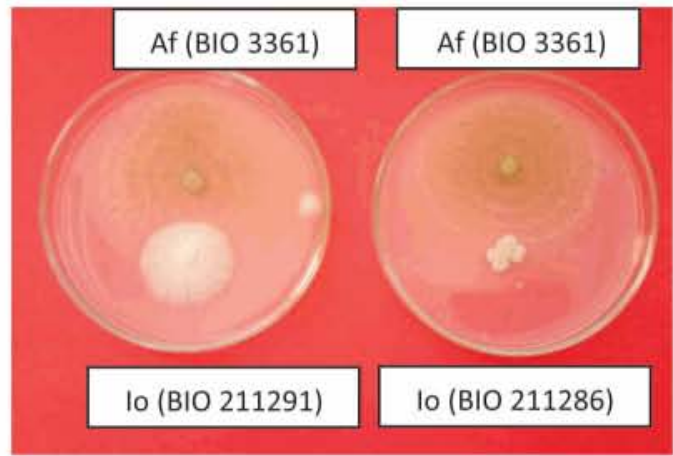

(a)

(b)

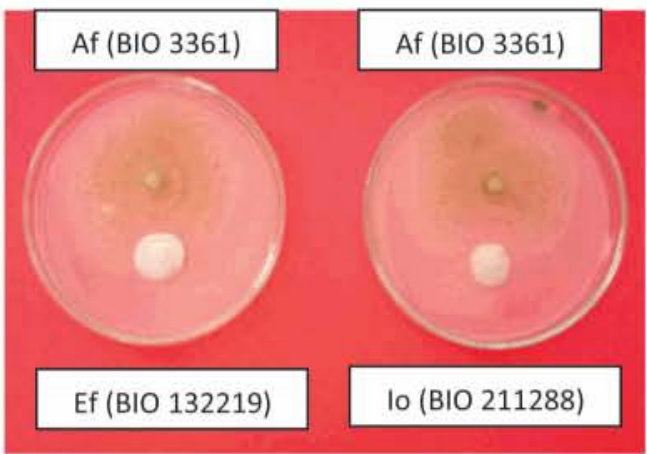

(c) (d)

Figure 3 Mechanism of interaction between four yeast isolates (Issatchenkia orientalis): (a) BIO 211291; (b) BIO 211286; (c) Endomyces fibuliger BIO 133219; and (d) I. orientalis BIO 211288); aflatoxigenic Asperyillus flavus on Potato Dextrose Agar (PDA) media after 7 days of incubation at room temperature $\left(28 \pm 2{ }^{\circ} \mathrm{C}\right)$

Table 1 Interaction types and the percentage of inhibition between yeast on aflatoxigenic Aspergillus flavus based on direct opposition method

\begin{tabular}{|c|c|c|c|c|c|}
\hline \multirow{2}{*}{ Isolate } & \multicolumn{2}{|c|}{ Mean of radius (mm) } & \multirow{2}{*}{$\%$ Inhibition } & \multirow{2}{*}{ Interaction type } & \multirow{2}{*}{ Interaction figure } \\
\hline & $\mathrm{J}_{1}$ & $\mathrm{~J}_{2}$ & & & \\
\hline $\begin{array}{l}\text { Issatchenkia orientalis } \\
\text { BIO } 211291 \text { vs } \text { A. flavus }\end{array}$ & 23.8 & 12 & $49.58 \mathrm{a}$ & $\mathrm{D}$ & b \\
\hline $\begin{array}{l}\text { I. orientalis BIO } 211288 \mathrm{vs} \\
\text { A. flavus }\end{array}$ & 23.75 & 15.25 & $35.79 \mathrm{~b}$ & $\mathrm{D}$ & b \\
\hline $\begin{array}{l}\text { I. orientalis BIO } 211286 \text { vs } \\
\text { A. flavus }\end{array}$ & 24 & 20.25 & $15.63 \mathrm{c}$ & A & \\
\hline $\begin{array}{l}\text { Endomyces fibuliger } \\
\text { BIO } 132219 \text { vs } A \text {. flavus }\end{array}$ & 28 & 14.2 & $49.29 \mathrm{a}$ & $\mathrm{D}$ & b \\
\hline
\end{tabular}


Antagonistic Test in Combination of Yeast, Acetobacter aceti and Mangosteen Rind Extract on Aflatoxigenic Aspergillus flavus In Vitro

According to Richard and Prusky (2002) yeast has some unique charactheristics such as fast growth, the ability to colonize surface of fruit, and the ability to join in nutrition competition with a pathogen, therefore it can be a biocontrol agent. Ycast also has an important role in fermentation, because it can convert glucose and maltose through anaerobic respiration. The well method is a method for determining on the percentage of inhibition between yeast and pathogenic fungi. All treatments except yeast controls were not inoculated by aflatoxigenic $A$. flavus.

Widiyanto et al. (2013) reported that unfermented cocoa beans has no any glucose, because the pulp has been removed. It means that additional material is needed to maintain beneficial microorganisms survival in unfermented cocoa beans. According to Maligan et al. (2018) mangosteen rind extract (MRE) contents in $100 \mathrm{~g}$ are $82.50 \%$ carbohydrate, $6.45 \%$ fats, $3.02 \%$ proteins, $5.87 \%$ water, and $2.10 \%$ total glucose. The nutritional content of MRE may increase the yeast survival. MRE also has xanthone for anticancer, antihyperglicemic, and antioxidant for human health. Other research, Acetobacter is one of bacteria that can oxidize glucose to gluconic and other organic acid in the same time to maintain the shelf life of foodstuff (Simanjuntak et al. 2016). Therefore, in this research, each of four yeast

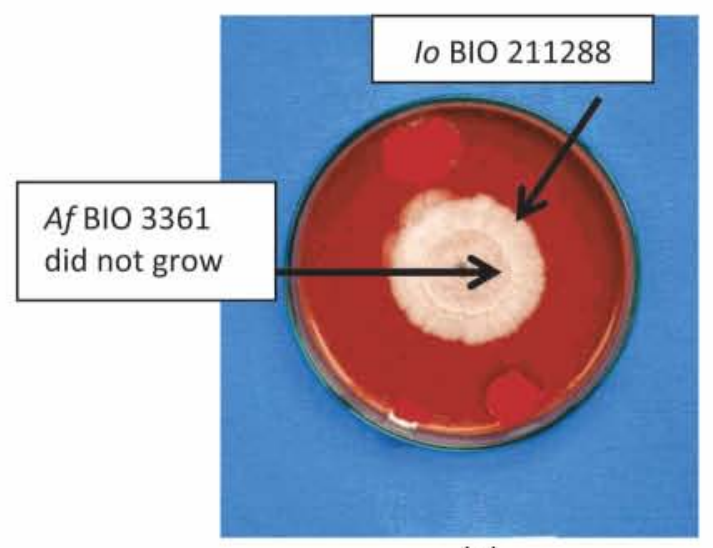

(a) isolates were combined with acetic acid bacteria and MRE in vitro stage to test the effectiveness of those treatment in different media (PDA + $15 \%$ cocoa beans juice with and without $12 \mathrm{~g} / \mathrm{L}$ MRE).

The highest percentage of inhibition on aflatoxigenic $A$. flavus BIO $3361 / 747$ was $100 \%$, in treatment with Issatchenkia orientalis BIO 211288 + Acetobacter aceti FNCC0016 on Potato Dextrose Agar (PDA) + 15\% cocoa beans juice $+12 \mathrm{~g} / \mathrm{L}$ mangosteen rind extract (MRE) media (Fig. 4a; Table 2). It means those treatment more effective than other treatments to against the aflatoxigenic $A$. flavus in vitro. The $2^{\text {nd }}$ highest percentage of inhibition was $51.98 \%$, in treatment $I$. orientalis BIO 211291 on PDA + $15 \%$ cocoa beans juice $+12 / \mathrm{g}$ MRE (Fig. 4b; Table 2). Hafsari (2011) explained that the differences in fungal diameter indicated that yeast growth is faster than that of fungi and it also obtained more nutrition than pathogenic fungi. The stunting growth of fungi was shown from the diameter of colony that was lower than the control $(+)$. According to Janisiewicz and Korsen (2002) the mechanism of space and nutrition competitions could happened if the yeast's effort was higher than pathogenic fungi to get nutrition and space. The similar research from Golubev (2006) explained that the capability of yeast antagonism would increase on other microorganism from different habitat, because the fungi are a new competitor that should be defeated to become a dominant in the available space and nutrition.

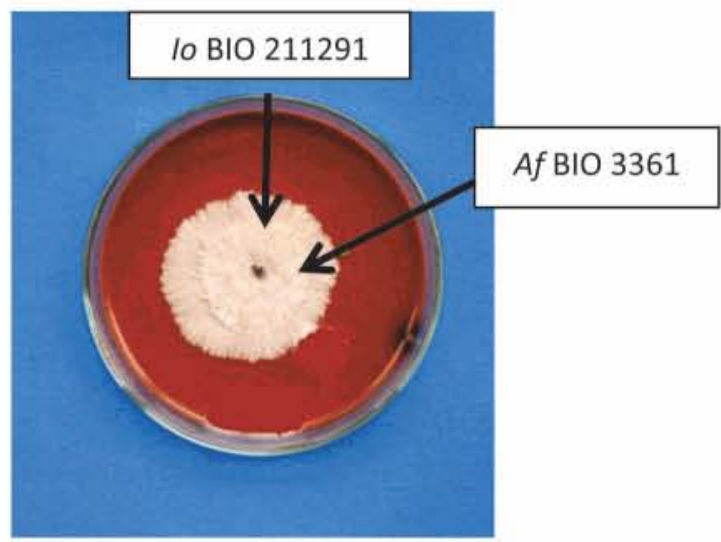

(b)

Figure 4 (a) Issatchenkia orientalis $\mathrm{BIO} 211288$ and (b) I. orientalis $\mathrm{BIO} 211291$ vs toxigenic A. flavus $\mathrm{BIO} 3361 / 747$ with Acetobacter aceti on Potato Dextrose Agar $+15 \%$ cocoa beans juice $+12 \mathrm{~g}$ MRE at room temperature $\left(27 \pm 2{ }^{\circ} \mathrm{C}\right)$ after 7 days of incubation 
Table 2 Effect of different combination and media treatments on the percentage of inhibition and growth of yeast, acetic acid bacteria, and aflatoxigenic $A$. flavus

\begin{tabular}{|c|c|c|c|c|c|}
\hline \multicolumn{2}{|l|}{ Treatment } & \multicolumn{3}{|c|}{ Diameter (mm) } & \multirow{2}{*}{$\begin{array}{c}\text { Inhibition } \\
(\%)\end{array}$} \\
\hline Combination & Media & Yeast & Acetobacter aceti & Aspergillus flavus & \\
\hline Issatchenkia orientalis $291+A$. flavus & \multirow{4}{*}{$\begin{array}{l}\text { PDA }+15 \% \text { cocoa } \\
\text { beans juice }\end{array}$} & 15.45 & - & 37.20 & 20.00 \\
\hline 1. orientalis $288+A$. flawus & & 27.35 & - & 30.15 & 25.56 \\
\hline I. orientalis $286+A$. flanus & & ND & - & 40.00 & 9.03 \\
\hline Endomyces fibuliger $219+$ A. flavus & & ND & - & 42.10 & 9.46 \\
\hline I. orientalis $291+A$. flavus & \multirow{4}{*}{$\begin{array}{l}\text { PDA }+15 \% \text { cocoa } \\
\text { beans juice }+12 \mathrm{~g} / \mathrm{L} \\
\text { mangosteen rind } \\
\text { extract }\end{array}$} & 25.50 & - & 34.17 & 26.52 \\
\hline I. orientalis $288+$ A. flavus & & 34.47 & - & 25.23 & 45.74 \\
\hline I. orientalis $286+$ A. flavus & & ND & - & 39.79 & 14.43 \\
\hline E. fibuliger $219+$ A. flavus & & ND & - & 38.13 & 18.00 \\
\hline \multirow{4}{*}{$\begin{array}{l}\text { 1. orientalis } 291+\text { Acetobacter aceti }+ \\
\text { Aspergillus flawus } \\
\text { 1. orientalis } 288+\text { A. aceti }+ \text { A. flavus } \\
\text { I. orientalis } 286+\text { A. aceti }+ \text { A. flavus } \\
\text { E. fibuliger } 219+\text { A. aceti }+ \text { A. flavus }\end{array}$} & \multirow{4}{*}{$\begin{array}{l}\text { PDA }+15 \% \text { cocoa } \\
\text { beans juice }\end{array}$} & 11.21 & ND & 30.60 & 34.19 \\
\hline & & 30.01 & ND & 24.57 & 47.16 \\
\hline & & ND & ND & 37.92 & 18.45 \\
\hline & & ND & ND & 39.44 & 15.18 \\
\hline I. orientalis $291+$ A. aceti + A. flavus & \multirow{4}{*}{$\begin{array}{l}\mathrm{PDA}+15 \% \text { cocoa } \\
\text { beans juice }+12 \mathrm{~g} / \mathrm{L} \\
\text { mangosteen rind } \\
\text { extract }\end{array}$} & 29.98 & 5.26 & 22.33 & 51.98 \\
\hline I. orientalis $288+$ A. aceti + A. flavus & & 34.45 & 18.62 & ND & 100.00 \\
\hline 1. orientalis $286+A$. aceti $+A$. flavus & & ND & ND & 40.87 & 12.11 \\
\hline E. fibuliger $219+$ A. aceti + A. flavus & & ND & ND & 39.77 & 14.47 \\
\hline I. orientalis 291 (control) & \multirow{5}{*}{$\begin{array}{l}\text { PDA }+15 \% \text { cocoa } \\
\text { beans juice }\end{array}$} & 35 & - & - & 0 \\
\hline I. orientalis 288 (control) & & 40 & - & - & 0 \\
\hline I. orientalis 286 (control) & & 15 & - & - & 0 \\
\hline E. fibuliger 219 (control) & & 11 & - & - & 0 \\
\hline A.flavus (control + ) & & - & - & 46.50 & 0 \\
\hline
\end{tabular}

Notes: $(-)=$ not inoculated; $\mathrm{ND}=$ not detected; $0=$ no inhibition (control).

Based on different yeast isolates, I. orientalis BIO 211291 and I. orientalis BIO 211288 were potential as a component inhibitor for A. flavus BIO 3361/747 in vitro. Based on different agar media, PDA $+15 \%$ cocoa beans juice $+12 \mathrm{~g} / \mathrm{L}$ MRE media was more effective than PDA + $15 \%$ cocoa beans juice media to inhibit aflatoxigenic $A$. flavus in vitro. It means that MRE influenced on decreasing of aflatoxigenic A. flavus growth in vitro. Yatman (2012) reported that xanthone of mangosteen rind extract can be used as antimicrobial, antioxidant, antifungi, and anticancer.

\section{Populations of Issatchenkia orientalis, Acetobacter aceti, and Aspergillus flavus In Vivo}

Two yeast isolates with the highest percentage of inhibition on aflatoxigenic A. flavus in vitro were Issatchenkia orientalis $\mathrm{BIO}$ 211291 and BIO 211288. The yeast isolates were used in vivo stage. The highest population of yeast $I$. orientalis of cocoa beans in 1 day after inoculation was $5.88 \log \mathrm{cfu} / \mathrm{g}$, found in samples inoculated by with I. orientalis BIO $211291+$ mangosteen rind extract (MRE) + A. flavus. The highest $I$. orientalis population in 3 and 6 days after inoculation were 4.67 and $3.75 \log \mathrm{cfu} / \mathrm{g}$, found in samples inoculated by $I$. orientalis $\mathrm{BIO}$ $211291+$ BIO $211288+$ A. aceti $+\mathrm{MRE}+A$. flavus. The highest $I$. orientalis population in 11 days after inoculation was $2.82 \log \mathrm{cfu} / \mathrm{g}$, found in samples inoculated by I. orientalis BIO 211291 or BIO $211288+\mathrm{MRE}+$ A. flavus (Table 3 ). The negative and positive controls, sample with Acetobacter aceti + mangosteen rind extract + A. flavus were not inoculated by $I$. orientalis. Based on different days after inoculation, commonly $I$. orientalis population in 3 day after inoculation was higher than 1, 6 and 11 days after inoculation. Yeast population in all samples with MRE were not significant different with samples without MRE.

Jamili et al. (2016) reported the dominant yeasts were found in cocoa beans during fermentation, i.e., 1 isolate Candida krusei, 3 isolates C. tropicalis, 1 isolate Saccharomycopsis fibuligera, 1 isolate Kloeckera sp., and 1 isolate Saccharomyces cerevisiae. According to Ren et al. (2020) many microorganisms including bacteria, non-toxigenic fungi, and yeast strains have been investigated as potential biocontrol agents against to aflatoxigenic fungi. Lee et al.(2008) reported that peroxisomal 3-ketoacyl-CoA thiolase 
(ScFox3) in Saccharomyces cerevisiae inhibited pathogenic fungi such as Botrytis cinerea, Didymella bryoniae, Fusarium moniliforme, F. solani, Penicillium verrucosum, Rhizoctonia solani, and $T$. harzianum. Other research, I. orientalis also has 3-ketoacylCoA, 3-hydroxyacyl-CoA, and trans-2-enol-CoA (WIPO-PC'T 2019). It means that I. orientalis also can be used as a component of biocontrol agents to inhibit aflatoxigenic $A$. flavus.

As many as 7 of the 12 cocoa beans were inoculated by $A$. aceti. The highest $A$. aceti population of cocoa beans in 1 and 11 day after inoculation were 4.22 and $3.12 \log \mathrm{cfu} / \mathrm{g}$, found in sample inoculated by $I$. orientalis BIO $2111291+$ BIO $211288+$ A. aceti + mangosteen rind extract (MRE) + A. flavus. Cocoa beans were inoculated by $I$. orientalis $\mathrm{BIO}$ $2111291+$ BIO $211288+$ A. aceti + A. flavus had the highest $A$. aceti population in 3 and 6 days after inoculation, i.e. 4.75 and $3.30 \mathrm{log}$ cfu/g (Table 3). Based on different days after inoculation, commonly the population of those in 3 days after inoculation was higher than 1, 6 , and 11 days after inoculation. Acetobacter aceti population in all samples with MRE were higher than samples without MRE, although the populations were not significant differences.

The activity of acetic acid bacteria took place after converting of glucose into alcohol and lactic acid. Ardhana and Fleet (2003) reported that the population of acetic acid bacteria (A. pasteurianus and $A$. acetz) were isolated in cocoa beans as much as $10^{5}-10^{6} \mathrm{cfu} / \mathrm{g}$. According to Simanjuntak et al. (2016) oxidation of glucose into gluconic acid and other organic acid in Acetobacter's activity aims to maintain the shelf life of foodstuff.

The highest population of $A$. flavus in 1 day after inoculation was $3.75 \log \mathrm{cfu} / \mathrm{g}$ in samples inoculated by I. orientalis BIO $211291+$ BIO $211288+$ A. aceti $+\mathrm{MRE}+$ A. flavus, meanwhile the lowest population of those was $0.48 \mathrm{log}$ $\mathrm{cfu} / \mathrm{g}$ in three samples (samples inoculated by $I$. orientalis $\mathrm{BIO} 211291+\mathrm{BIO} 211288+$ A. aceti + $\mathrm{MRE}+A$. flavus and samples inoculated by $I$. orientalis $\mathrm{BIO} 211288+A$. aceti $+A$. flawus with and without MRE). The highest population of A. flavus in 3 days after inoculation was $3.56 \mathrm{log}$ $\mathrm{cfu} / \mathrm{g}$ in positive control, meanwhile the population was not found in samples inoculated by $I$. orientalis BIO $211291+I$. orientalis BIO $211288+$ Acetobcter aceti + MRE + A. flavus and
I. orientalis $\mathrm{BIO} 211291$ or $\mathrm{BIO} 211288+$ $A$. aceti + mangosteen rind extract $+A$. flawns. The highest population of $A$. flavus in 6 days after inoculation was $4.43 \mathrm{log} \mathrm{cfu} / \mathrm{g}$ in positive control, meanwhile the population was not found in samples with I. orientalis BIO $211291+$ I. orientalis $\mathrm{BIO} 211288+A$. aceti $+\mathrm{MRE}+$ A. flavus, I. orientalis BIO $211288+A$. aceti + $\mathrm{MRE}+A$. flavus, and $A$. aceti $+\mathrm{MRE}+$ $A$. flavus. The highest population of $A$. flavus in 11 days after inoculation was $3.97 \log \mathrm{cfu} / \mathrm{g}$ in negative control, meanwhile the population was not found in samples inoculated by $I$. orientalis BIO $211291+$ I. orientalis BIO $211288+$ $A$. aceti $+A$. flavus with and without MRE, I. orientalis $\mathrm{BIO} 211288+A$. aceti + mangosteen rind extract $+A$. flavus (Table 3 ).

Based on different days after inoculation, $A$. flavus population of cocoa beans in 1 day after inoculation was higher than 3, 6, and 11 days after inoculation. Aspergillus flavus population in all samples with MRE were lower than samples without MRE. It means that combination treatment with MRE addition is more appropriate to inhibit aflatoxigenic $A$. flavus population. Two best combination treatments to against aflatoxigenic $A$. flavus in unfermented cocoa beans were I. orientalis BIO $211291+$ I. orientalis $\mathrm{BIO} 211288+A$. aceti $+\mathrm{MRE}$ and samples inoculated by $I$. orientalis $\mathrm{BIO}$ $2112288+A$. aceti + MRE, because A. flavus population of those treatment was not found in 3 up to 11 days after inoculation (Table 3). According to Aisha et al. (2012) mangoteen rind extract compunds are xanthone extract, $\alpha$ mangostin, and $\gamma$-mangostin. Each compound inhibited $50 \%$ of cancer cell in $6.5 \pm 1.0$ $\mathrm{mg} / \mathrm{mL}, 5.1 \pm 0.2 \mu \mathrm{g} / \mathrm{mL}$, and $7.2 \pm 0.4$ $\mu \mathrm{g} / \mathrm{mL}$. Rubiyanti et al. (2017) also reported that $\alpha$-mangostin and gartanin infulenced in biological activity such as antifungi and anticancer.

Foodstuff could be infested by insects, microorganisms, mites and rats during storage. Among microorganisms, fungi are the most important cause of deterioration of stored grains or seeds. Fungal infection in grains cause discolouration, decreases in physical quality and nutritional contents, and mycotoxin contamination (Sauer et al. 1992). According to Waliyar et al. (2015) the main factors that 
influence the ability of $A$. flavus growth during storage are temperature, relative humidity, and moisture content. Norlia et al. (2019) also reported that relative humidity and water activity $\left(a_{w}\right)$ in foods are interrelated to each other and could be used to determine the ability of fungal growth. Not only temperature, relative humidity and water activity, but also $\mathrm{CO}_{2}$ levels influence the fungal growth (Giorni et al. 2018).

Table 3 Issatchenkia orientalis, Acetobacter aceti and Aspergillus flavus populations in unfermented cocoa beans with combination treatments since 1 until 11 days after inoculation

\begin{tabular}{|c|c|c|c|c|c|c|c|c|c|c|c|c|}
\hline \multirow{3}{*}{ Treatment } & \multicolumn{4}{|c|}{$\begin{array}{l}\text { Issatchenkia orientalis population } \\
\qquad(\log \mathrm{cfu} / \mathrm{g})\end{array}$} & \multicolumn{4}{|c|}{$\begin{array}{l}\text { Acetobacter aceti population } \\
\qquad(\log \mathrm{cfu} / \mathrm{g})\end{array}$} & \multicolumn{4}{|c|}{$\begin{array}{c}\text { Aspergillus flavus population } \\
\text { (log cfu/g) }\end{array}$} \\
\hline & \multicolumn{4}{|c|}{ Day after inoculation } & \multicolumn{4}{|c|}{ Day after inoculation } & \multicolumn{4}{|c|}{ Day after inoculation } \\
\hline & 1 & 3 & 6 & 11 & 1 & 3 & 6 & 11 & 1 & 3 & 6 & 11 \\
\hline $\begin{array}{l}\text { Negative control } \\
\text { (without } \\
\text { inoculation of } \\
\text { microorganisms) }\end{array}$ & - & - & - & - & - & - & - & - & - & - & - & 3.97 \\
\hline $\begin{array}{l}\text { I. orientalis } 291+ \\
\text { I. orientalis } 288+ \\
\mathrm{MRE}+\text { A. flavus }\end{array}$ & 2.52 & 3.80 & 2.90 & 2.73 & - & - & - & - & 2.52 & 2.48 & 0.48 & 0.48 \\
\hline $\begin{array}{l}\text { I. orientalis } 288+ \\
\mathrm{MRE}+\text { A. flavus }\end{array}$ & 4.38 & 4.30 & 3.20 & 2.82 & - & - & - & - & 1.51 & 0.48 & 0.48 & 0.48 \\
\hline $\begin{array}{l}\text { 1. orientalis } 291+ \\
\mathrm{MRE}+\text { A. flavus }\end{array}$ & 5.88 & 3.75 & 2.82 & 2.82 & - & - & - & - & 3.23 & 2.12 & 1.83 & 1.89 \\
\hline $\begin{array}{l}\text { * I. orientalis } 291+ \\
\text { I. orientalis } 288+ \\
\text { Acetobacter aceti }+ \\
\mathrm{MRE}+\text { A. flavus }\end{array}$ & 3.12 & 4.67 & 3.75 & 2.52 & 4.22 & 3.30 & 2.75 & 3.12 & 3.75 & ND & ND & ND \\
\hline $\begin{array}{l}\text { I. orientalis } 291+I \text {. } \\
\text { orientalis } 288+ \\
\text { Acetobacter aceti }+ \\
\text { A. flavus }\end{array}$ & 3.43 & 4.12 & 2.78 & 1.94 & 3.52 & 4.75 & 3.30 & 2.14 & 0.48 & 1.48 & 1.23 & ND \\
\hline $\begin{array}{l}\text { I. orientalis } 288+ \\
\text { Acetobacter aceti }+ \\
\text { A. flavus }\end{array}$ & 2.00 & 4.12 & 2.43 & ND & 2.43 & 2.48 & 2.88 & 2.64 & 0.48 & 0.48 & 3.08 & 2.22 \\
\hline $\begin{array}{l}\text { 1. orientalis } 291+ \\
\text { Acetobacter aceti }+ \\
\mathrm{MRE}+\text { A. flavus }\end{array}$ & 3.07 & 4.64 & 2.12 & ND & 3.26 & 4.73 & 2.37 & 2.37 & 2.74 & ND & 1.00 & 1.52 \\
\hline $\begin{array}{l}\text { * I. orientalis } 288+ \\
\text { Acetobacter aceti }+ \\
\text { MRE }+ \text { A. flavus }\end{array}$ & 3.22 & 4.12 & 2.12 & ND & 3.75 & 3.56 & 2.12 & 2.00 & 0.48 & ND & ND & ND \\
\hline $\begin{array}{l}\text { I. orientalis } 291+ \\
\text { Acetobacter aceti }+ \\
\text { A. flavus }\end{array}$ & 3.56 & 3.60 & 2.67 & ND & 2.12 & 2.48 & 2.87 & 2.80 & 2.75 & 2.00 & 2.94 & 3.48 \\
\hline $\begin{array}{l}\text { A. aceti }+\mathrm{MRE}+ \\
\text { A. flavus }\end{array}$ & - & - & - & - & 4.10 & 3.37 & 2.78 & 2.11 & 1.83 & 1.51 & ND & 1.72 \\
\hline $\begin{array}{l}\text { Positive control } \\
\text { (A. flavus) }\end{array}$ & - & - & - & - & - & - & - & - & 3.00 & 3.56 & 4.43 & 3.85 \\
\hline
\end{tabular}

Notes: MRE = mangosteen rind extract; $\mathrm{ND}=$ not detected; $(-)=$ not inoculated. 


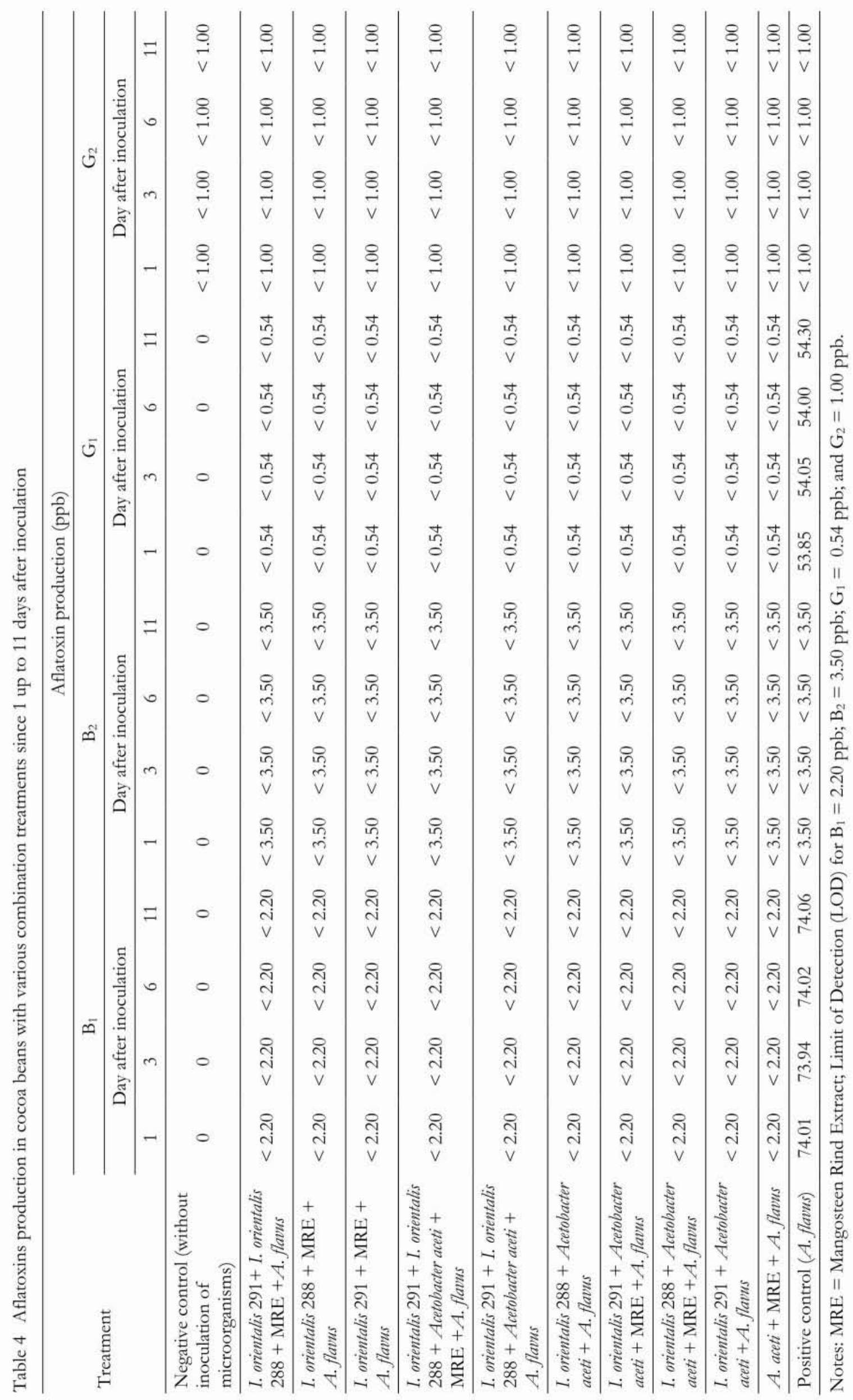


Range of temperature and relative humidity in the storage room after cocoa beans inoculation with various treatments were 27 . $28{ }^{\circ} \mathrm{C}$ dan $78-80 \%$. Water activity and $\mathrm{CO}_{2}$ levels were not determined in this research. Suttajit (2014) reported that the optimum temperature for fungal growth was $25-40{ }^{\circ} \mathrm{C}$.

Aflatoxins content in positive control were aflatoxin $B_{1}$ (74.01 ppb), $G_{1}(54.05 \mathrm{ppb})$, and total aflatoxin (128.06 ppb), while all sample treatments included negative control contained aflatoxin $\mathrm{B}_{1}$ were lower than the limit detection, i.e., $B_{1}(<2.20 \mathrm{ppb}), \mathrm{B}_{2}(<3.50 \mathrm{ppb}), \mathrm{G}_{1}(<0.54$ $\mathrm{ppb})$, and $\mathrm{G}_{2}(<1.00 \mathrm{ppb})$ (Table 4). There were no significant differences between combination treatments on aflatoxin production.

It means that all unfermented cocoa beans with combination treatments within or without mangosteen rind extract could be processed into chocolate products, because the aflatoxins were relatively safe. According to Mazumder and Sasmal (2001) the maximum tolerable limit for aflatoxin in cocoa beans, cocoa butter, and cocoa powder in Bulgaria are $5 \mathrm{ppb}$, while in Uruguay and Malaysia the limits are $10 \mathrm{ppb}$.

According to Scott and Pryzbylski (2020) the range of aflatoxins in raw cocoa beans from Trinidad and Ghana was $8-35 \mu \mathrm{g} / \mathrm{kg}$. Maciel $e t$ al. (2018) reported as much as $38 \%$ cocoa beans in southern region of Bahia, Brazil were contaminated by aflatoxin in the range < LOD$17.795 \mu \mathrm{g} / \mathrm{kg}, 25 \%$ and $18 \%$ of total samples were contaminated by AFB1 and ochratoxin A in the range of $<\mathrm{LOD}-274.90 \mu \mathrm{g} / \mathrm{kg}$.

\section{CONCLUSION}

There were 2 kinds of interaction types obtained from the antagonisms test between 4 yeasts (I. orientalis BIO 211291, BIO 211288, BIO 211286, and Endomyces fibuliger BIO 132219) and aflatoxigenic $A$. flavus, i.e., type D and A. The best combination treatment in vitro was found in unfermented cocoa beans with $I$. orientalis BIO $211288+$ Acetobacter aceti $+A$. flavus on Potato Dextrose Agar with 15\% cocoa beans juice and $12 \mathrm{~g} / \mathrm{L}$ mangosteen rind extract media. Two best treatments in unfermented cocoa beans in vivo were found in samples inoculated by $I$. orientalis BIO $211291+$ BIO $211288+A$. acet $i+$ mangosteen rind extract and
I. orientalis $\mathrm{BIO} 211288+A$. aceti + mangosteen rind extract, because $A$. flavus was not grown in the samples for 3 until 11 days after inoculation. Based on aflatoxins content, all combination treatments were relatively safe to be processed, because its very low.

\section{ACKNOWLEDGMENTS}

The authors gratefully acknowledge the financial support through Daftar Isian Pelaksanaan Anggaran (DIPA) 2019 and SEAMEO BIOTROP. Thanks are due to Director of SEAMEO BIOTROP and Research Laboratory Supervisor for giving permission on using of laboratory facilities, to Ms. Okky Setyawati Dharmaputra and to Mrs. Ina Retnowati for her suggestion, Mrs. Ratnaningsih and Mrs. Syifa Fauzia for their assistance.

\section{REFERENCES}

Agricultural Department [Internet]. 2010. Pencanangan gerakan nasional fermentasi kakao untuk mendukung industri dalam negeri (The declaration of the national movement for cacao fermentation to support the domestic industry); [updated 2010; cited 2018 Nov 1]. Available from: www.deptan.go.id.

Aisha AFA, Abu-Salah KM, Ismail Z, Majid AMSA. 2012. In vitro and in vivo anti-colon cancer effects of Garcinia mangostana xanthones extract. Compl and Alternative Med 12:1-10.

Akao Y, Nakagawa Y, Linuma M, Nozawa Y. 2008. Anticancer effects of xanthones from pericarps of mangosteen. Int J of Mol Sci 9:355-70.

Ardhana M, Fleet G. 2003. The microbial ecology of cocoa bean fermentations in Indonesia. Int J of Food Microbiol 86(1):87-99.

Asrul. 2009. Populasi jamur mikotoksigenik dan kandungan aflatoksin pada beberapa contoh biji kakao (Theobromae cocoa) (Mycotoxigenic fungi population and aflatoxin content in several examples of cacao beans) (Theobromae cocoa). J Agroland 16(3):258-67.

Baiton SJ, Coker RD, Jones BD, Morley EM, Nagler MJ, Turner RL. 2006. Mycotoxin Training Manual. London (GB): Tropical Products Institute.

Basappa SC. 2009. Aflatoxins; Formation, Analysis and Control. New Delhi (IN): Narosa Publishing House.

Copetti MV, Iamanaka BT, Pereira JL, Fungaro MH, Taniwaki MH. 2011. Aflatoxigenic fungi and aflatoxin in cocoa. Int $\mathrm{J}$ of Food Microbiol $148(2): 141-4$. 
Dharmaputra OS, Retnowati I, Nurfadila N. 2018a. Potency of yeast as biocontrol agent of ochratoxin A producing fungi and its effect on the taste of Arabica coffee. Research Report. Bogor (ID): SEAMEO BIOTROP.

Dharmaputra OS, Sudirman LI, Misnawati MM. 2016. Potensi khamir sebagai agen pengendalian hayati Colletotrichum capsici, cendawan penyebab antraknosa pada buah cabai (Potency of yeast as biological control agent of Colletotrichum capsici; fungal causing anthracnose in chilli). J Hort Indonesia 7(2):89100.

Dharmaputra OS, Sudirman I, Ratnaningsih EA. 2018b. Mikobiota pada buah pisang kultivar Lampung untuk pengendalian hayati Fusarium semitectum (Mycobiota on banana fruit Lampung cultivar for biological control of Fusarium semitectum). JFI 14(1):30-8.

Dickson [Internet]. 2017. Sepuluh negara penghasil kakao terbesar di dunia (The biggest of ten producing cocod beans countries in the world). [updated 2017; cited 2018 Mar 14]. Available from: https:// ilmupengetahuanumum.com/10-negara-penghasilkakao-terbesar-di-dunia/.

Giorni P, Battilani P, Pietri A, Magan N. 2008. Effect of water activity and $\mathrm{CO}_{2}$ levels on Aspergillus flavus growth and aflatoxin production in high moisture maize postharvest. Int Journal of Food Microbiol. 122(1):109-13.

Golubev WI. 2006. Antagonistic Anteractions among Yeast. Germany (DE): Springer. p 197-219.

Hafsari AR, Ariyanti O, Andi S, Wellyzar S. 2011. Pengujian kemampuan antagonistik khamir Rhodotorula spp. asal Kebun Raya Cibodas terhadap kapang dari tanaman tomat terinfeksi dengan coculture (Testing the antagonistic potency of Rhodotorula spp yeast from Cibodas Botanical Garden against fungi from tomato plant infected with co-culture). Researchgate 5(1):149-60.

Indonesian National Standard. 2008. Biji Kakao SNI 2323:2008 (Cocoa beans SNI 2323:2008). Jakarta (ID): National Standardization Company.

Jamili, Yanti NA, Susilowati PE. 2016. Diversity and the role of yeast spontaneous cocoa bean fermentation from Southeast Sulawesi, Indonesia. Biodiversitas 17(1):90-5.

Janisiewicz WJ, Korsen L. 2002. Biological control of postharvest diseases of fruits. Annu Rev Phytopathol 40:11-441.

Kusumaputri S. 2011. Dosis aman ratu buah (Queen of fruit safe dosage). [updated 2017; cited 2018 Apr 11]. Available from: https//www.trubus-online.co.id/ dosis-aman-ratu-buah/

Lee JR, Kim SY, Chae HB, Jung HJ, Lee SY. 2008. Antifungal activity of Saccharomyces cerevisiae peroxisomal 3-ketoacyl-CoA thiolase. BMB reports p.281-5.
Maciel LF, Felicio ALSM, Miranda LCR, Pires TC, Bispo ES, Hirooka EY. 2018. Aflatoxins and ochratoxin A in different cocoa clones (Theobromae cacao L.) developed in the southern region of Bahia, Brazil. Food Additives and Contaminants: Part A 35(1):134-43.

Maligan JM, Chairunnisa F, Wulan SN. 2018. Peran xanthon kulit buah manggis (Garcinia mangostana L.) sebagai agen antihiperglikemik (The role of mangosteen's skin (Garcinia mangostana L.) xanthone as antilyperglicemic agent. Jurnal Ilmu Pangan dan Hasil Pertanian 2(2):99-106.

Mazumder PM, Sasmal D. 2001. Mycotoxins-limit and regulations. Ancient Sci of Life 20(1):1-19.

Norlia M, Jinap S, Nor-Khaizura MAR, Radu A, Samsudin NIP, Azri FA. 2019. Aspergillus section Flavi and aflatoxins: occurrence, detection, and identification in raw peanuts and peanut-based products along the supply chain. Frontiers in Microbiology 10(1):1-17.

Nurhansyah V [Internet]. 2011. Biji kakao Indonesia ditinggalkan oleh pembeli (Indonesian cacao beans abandoned by buyers). [updated 2011; cited 2018 Sept 9]. Available from: http://industri.kontan.co.id/ news/biji-kakao-indonesia-ditinggalkan-parapembeli.

Pires PN, Vargas EA,Gomes MB, Vieira CBM, dos Santos EA, Bicalho AAC, Silva SC, Rezende RP, De Oliveira IS, Martins ED, Luz N, Uetanabaro APT. 2019. Aflatoxins and ochratoxin A : occurrence and contamination levels in cocoa beans from Brazil. Food Additives and Contaminants: Part A 36(5):1-10.

Richard WJ, Prusky D. 2002. Expression of an antifungal peptide in Saccharomyces: a new approach for biological control of the postharvest disease caused by Colletotrichum coccodes. Phytopathol 92(1):33-7.

Ren X, Zhang Q, Zhang W, Mao J, Li P. 2020. Control of aflatoxigenic molds by antagonistic microorganisms: inhibitory behaviors, bioactive compounds, related mechanisms and influencing factors. Toxins 12(24):1-21.

Rubiyanti R, Susilawati Y, Muchtaridi M. 2017. Potensi ekonomi dan manfaat kandungan $\alpha$ - mangostin serta gartanin dalam kulit buah manggis (Garcinia mangostana Linn.) (Economic and benefits potential amangostin and gartanin mangosteen rind (Garcinia mangostana Linn.). Farmaka 15(1):15-25.

Sabahannur St, Ralle. 2018. Peningkatan kadar alkohol, asam dan polifenol limbah cairan pulp biji kakao dengan penambahan sukrosa dan ragi (Increasing of alcobol, acid and polyphenol levels in the liquid waste of cocoa beans pulp with the addition of sucrose and yeast). Jurnal Industri Hasil Perkebunan 13(1):53-61.

Sauer DB, Meronuck RA, Christensen CM. 1992. Microflora. Dalam Sauer DB (editor). Storage of Cereal Grains and Their Product. $4^{\text {th }}$ ed. Minnesota: 
American Association of Cereal Chemist. pp. 31340.

Scott PM, Pryzbylski W. 2020. Collaborative study of a method for the analysis of cocoa beans for aflatoxins. Journal of Association of Official Analytical Chemists 54(3):540-4.

Simanjuntak DH, Herpandi, Lestari SD. 2016. Karakteristik kimia dan aktivitas antioksidan kombucha dari tumbuhan Apu-apu (Pistia stratiotes) selama fermentasi. Jurnal Hasil Teknologi Perikanan 5(2):123-33.

Suttajit M [Internet]. 2014. Prevention and control of mycotoxins FAO Corporate Document Repository. [uupdated 2018; cited 2019 Jul 11]. Available from: http://www.fao.org/docrep/x5036e/x5036EOq.h tm.

Thompson SS, Miller KB, Lopez A, Camu N. 2013. Cocoa and coffee. In: Doyle MP, Buchanan RL, editor. Food Microbiology: Fundamentals and Frontiers. Washington DC (US): ASM Press. Ed.4. p.881-9.
Waliyar F, Osiru M, Ntare BR, Kumar KVK, Sudini H, Traore A. 2015. Postharvest management of aflatoxin contamination in groundnut. World Mycotoxin Journal 8:245-52.

Wheeler KA, Hocking AD. 1993. Interactions among xerophilic fungi associated with dried salted fish. J Applied Bacteriol 74:164-9.

Widiyanto D, Pramita AD, Wedhastari S. 2013. Perbaikan proses fermentasi biji kakao kering dengan penambahan tetes tebu, khamir, dan bakteri asam asetat (Improvement of the fermentation process for $d r y$ cocoa beans by adding molasses, yeast, and acetic acid bacteria). Jurnal Tekno Sains 3(1):38-44.

WIPO-PCT [World Intelectual Property OrganizationPatent Cooperation Treaty]. 2019. WO2019/ 036202 A1. Minnesota (US): Patent Cooperation Treaty.

Yatman E. 2012. Kulit buah manggis mengandung xanton yang berkhasiat tinggi (Mangosteen rind contains xanthone, which is bighly beneficial). Wawasan 29(324):1-9. 